\title{
ПОЕТИЧНА МОВОТВОРЧІСТЬ А. М. ПОПОВСЬКОГО
}

Розвідку присвячено дослідженню лінгвістичної зреалізованості поетичного мислення А. М. Поповського як висококультурної, компетентної мовної особистості, носія елітарної мовної культури. Окреслено складники поетичної картини світу А. М. Поповського, досліджено його поетичну мовну особистість, виділено важливі для поета концепти, риси поетичного мовомислення й авторського словотвору. Установлено, щзо аналізована поезія має діалогічний вимір, експлікований у декількох типах адресатів. 3'ясовано, щуо поезіям А. М. Поповського властивий осібний стиль, характерне органічне поєднання національного образного світу й власне авторського, філософськи осмисленого погляду на життя.

Ключові слова: мовотворчість, елітарна мовна особистість, компетентна мовна особистість, поетична мовна особистість, поетичне мислення, стиль, адресат.

Nevska Yu. A. M. Popovskyi's Poetic Linguo-Creativity. The work is devoted to the study of the linguistic realization of A. M. Popovskyi's poetic thinking as a highly cultured, competent linguistic personality and the bearer of an elite speech culture. This aim involves solving the following tasks: to analyze the author's poetic thinking and highlight the main concepts in his poetic works; to identify and describe the stylistic means and techniques that make up A. M. Popovskyi's linguistic personality and to characterize it. As a result, the components of A. M. Popovskyi's poetic picture of the world have been defined; his poetic linguistic personality has been studied. The concepts that are important for the poet, the characteristics of his poetic thinking and language, as well as the author's word formation have been highlighted. It has been established that A. M. Popovskyi's poetry has a dialogical dimension that is explicated in several types of addressees, in particular, living beings (generalized images - Ukrainians, Cossacks - and images of God and different people) and personified images (language, years, cuckoo, hope etc.). It has been found out that A. M. Popovskyi's poems have an inherent original style, which is characterized by the frequent use of metaphors, personifications, occasionalisms, folklore motives, in particular folk vocabulary and syntax, which, however, require more detailed research. It has been defined that the frequent use of appositions is a special feature of the author's poetic style. In the texts of poetry, phrases containing common root derivatives have been relatively frequent. Such tautological combination of derived words has contributed to the condensation of the utterance. The conclusion has been made that A. M. Popovskyi's poetic linguistic picture of the world is characterized by an organic combination of the national figurative world and the actual author's philosophical views. 
Furthermore, the collection of philosophical poems by A. M. Popovskyi presents original artistic works in which the pearls of the author's life wisdom are manifested in an expressive and unique author's style.

Key words: linguo-creativity, elite linguistic personality, competent linguistic personality, poetic linguistic personality, poetic thinking, style, addressee.

\section{Вступ}

Антропоцентрична зорієнтованість сучасної мовознавчої науки збільшує зацікавленість дослідників вивченням мовної особистості, а надто - висококультурної творчої мовної особистості.

B. I. Кононенко справедливо вважає, що «велети українського письменства $<\ldots>>$ зуміли відбити у своїй творчості як власні риси видатної особистості, так і - що особливо прикметно - загальнонародну вдачу, той національний характер, який і виокремлює українство як планетарне загальносвітове явище» (Кононенко, 2004: 234). Саме такою постаттю вважаємо відомого мовознавця, історика української мови, діалектолога, доктора філологічних наук, професора Анатолія Михайловича Поповського, за авторства якого вийшла у світ поетична збірка «У роздумах плинного часу...» (2020). Збірка містить творчі надбання знаного філолога, який є автором цілої низки ліричних і лірико-патріотичних поезій, написаних протягом близько шістдесяти років (з 1962 по 2020 роки).

Мова поезії «не може розглядатися як певний набір мовних засобів, оскільки матеріалізує естетично вартісні смисли» (Калашник, 2011: 248). Поетична мова окремого поета як висококультурної творчої мовної особистості є продуктом його мовотворчості, складником його індивідуальної поетичної картини світу й становить унікальне мовно-естетичне й культурне явище. Це й зумовлює актуальність нашої розвідки, оскільки мовна особистість А. М. Поповського як поета ще не була вивчена.

Мета цієї статті - з'ясувати характеристики поетичного мовомислення А. М. Поповського як висококультурної, компетентної мовної особистості, носія елітарної мовної культури; окреслити лінгвістичну зреалізованість його мовотворчості.

Зазначена мета передбачає розв'язання таких завдань: 1) проаналізувати мовомислення поета й виділити головні концепти в його поетичних творах; 2) виокремити й описати стилістичні засоби 
та прийоми, що становлять мовну особистість А. М. Поповського, схарактеризувати їі.

Об’єктом розгляду в цій статті є мовна особистість А. М. Поповського. Предмет дослідження - поетична мовна особистість А. М. Поповського.

\section{Методи дослідження}

Основними методами дослідження є загальнонаукові методи аналізу та синтезу й описовий метод для систематизації дібраного матеріалу й опису відповідних текстових одиниць; а також герменевтичний метод - для з'ясування глибинного смислу поезій А. М. Поповського, його мовно-філософських поглядів; метод контекстуального аналі$3 y$ - для виявлення провідних концептів у його поетичних творах; метод семантико-стилістичного аналізу - для з'ясування стрижневих стилеутворювальних компонентів у текстах аналізованих поезій.

\section{Виклад основного матеріалу}

Сьогодні вивчають лінгвоперсонологію й розробляють науковий апарат цієї порівняно нової галузі мовознавства А. П. Загнітко, I. Г. Данилюк та ін. До ядрових уналежнюють такі категорії лінгвоперсонології: «мовна особистість», «мовна свідомість», а також категорії «мовна картина світу», «когнітивна картина світу» (Загнітко, 2016: 156).

Історію поняття мовна особистість простежуємо від В. В. Виноградова, Ю. М. Караулова, В. І. Карасика та ін. Зверталися до поняття мовної особистості й різнопланово розробляли його теорію на вітчизняних теренах І. О. Голубовська, П. Ю. Гриценко, С. Я. Єрмоленко, Н. М. Сологуб, Л. В. Струганець та ін. Мовну особистість видатних майстрів художнього слова у вітчизняному мовознавстві досліджували Л. І. Мацько, В. С. Калашник, Т. А. Космеда, М. В. Скаб, К. Ю. Голобородько, А. П. Романченко, Т. І. Должикова та ін. За рівнем сформованості мовно-комунікативної компетентності Т. А. Космеда виокремлює сильну, посередню та слабку мовні особистості (Космеда, 2012: 43). Елітарну мовну особистість розрізняють О. Б. Сиротиніна, Л. I. Мацько (Мацько, 2014) та ін. Ми виокремлюємо компетентну мовну особистість, що має високий рівень лінгвістичної, прагматичної та соціокультурної компетентностей і розмовні та письмові 
дискурси якої мають культурну, наукову цінність для нації, суспільства та заслуговують на збереження і вивчення (Невська, 2019: 64-65). Така мовна особистість активно відбиває та поширює в часі, просторі й соціумі власну картину світу відповідно до різних комунікативних потреб з тенденцією до розвитку.

Дослідники, зокрема Л. І. Мацько, відзначають необхідність «вивчати окремі елітарні мовні особистості українського народу, їх мовну спроможність, мовні й мовленнєво-комунікативні компетенції з метою поширення <..> кращих зразків українського мовлення, вітчизняної риторики, відповідних національно специфічних мовнокомунікативних стратегій і тактик, символіки і тропіки» (Мацько, 2014: $11)$.

Поети, як відомо, мислять образами. Майстри слова аналізують дійсність, абстрагують, синтезують та узагальнюють явища об’єктивного світу й так пізнають його. Поети помічають і відбирають яскраво відчутні деталі пізнаваних явищ, у яких виявляється суть явищ, що потім узагальнюють у типових образах (Романченко, 2013: 44). Отже, уважаємо, що поетична картина світу поета складається з типових для його мовомислення образів, або концептів. Для поетичної картини світу А. М. Поповського такими концептами є СЛОВО, БАТЬКІВЩИНА, ПРАВДА, ПРАЦЯ, ДНІПРО, КОЗАЦТВО, ЩАСТЯ. Ці образи є найбільш частотними в дискурсі аналізованих поезій, а тому ядровими (Загнітко, 2016: 155), смислостворювальними ії компонентами. Спостерігаємо, що згадані концепти реалізуються в аналізованих поезіях у складі словосполучень з оцінною лексикою: мова трагічної долі (Поповський, 2020: 9), мудрість Всевишнього (Поповський, 2020: 9), знедолена Вкрайна (Поповський, 2020: 20), козацькая воля (Поповський, 2020: 49), козацькая слава, козацький степ, овіяний вітрами (Поповський, 2020: 8), в праці натхненній (Поповський, 2020: 40) та ін., навколо яких будується дискурс. Чи не найбільше смислове навантаження несуть словосполучення з концептом СЛОВО / МОВА. Мова в поета - це зоря світанкова, невмируща нації сила всевладна, яка розквітне трояндно в шані людській всюдисущза. СЛОВО - живе і рідне (Поповський, 2020: 7), у ніжнім слові автор бажає юним золотого співу (Поповський, 2020: 45). Сила слова (Поповський, 2020: 9, 64 та ін.) реалізується як мрія пророча Тараса й мудрість Всевишнього (Поповський, 2020: 9). 
Поезія А. М. Поповського має діалогічний вимір, що свідчить про прагнення автора спілкуватися зі своїм читачем. Це вдумлива й спокійна розмова про життєві цінності й пріоритети, про власні емоції, бажання та почуття. Ліричний герой, він же й автор поезій, звертається до читача, про що свідчать численні імперативи, активно залучає до споглядання: Глянь-но, подивися! (Поповський, 2020: 27); до осмислення дійсності: Народе мій! Не дай себе дурити... (Поповський, 2020: 23); дає мудрі поради: Ні кроку не ступай назад, Хоч келих лиха спив доволі (Поповський, 2020: 22), Любімось, братіє, допоки дух жиє (Поповський, 2020: 38) та ін.

Адресатами для поета є як увесь український народ (Народе мій! (Поповський, 2020: 23)), узагальнений образ українця (Вкраӥнцю мій, братіє, Юносте співоча і дзвінка! (Поповський, 2020: 45)), Всевишній (Отче сильний, святий! (Поповський, 2020: 42)), окрема людина (Олено Теліго! (Поповський, 2020: 65), зокрема син і дружина (Берегине моя (Поповський, 2020: 55)). Поет вносить і себе до кола братів-українців: Любімось, братіє (Поповський, 2020: 38); Не плачмо i не злімось, щзо вже тіта злетіли (Поповський, 2020: 38); до кола чоловіків-українців: Не скупімось на щиреє слово сказати для фей неземний комплімент (Поповський, 2020: 54). Адресатами також стають персоніфіковані образи, як-от: Мово моя материнська! (Поповський, 2020: 9). Такі образи часто є складниками імперативних конструкцій з вигуками, що надає поезіям емоційного, запального характеру: Гей, літа, не спішіть!, Гей, зозуле, накуй у дубовім гаю (Поповський, 2020: 56).

Своє завдання поет убачає в тому, щоб на власному прикладі показати, як потрібно жити, навчити «любити ці рідні краї» (Поповський, 2020: 56). Саме тому автор використовує фольклорні елементи, зокрема народнопісенні мотиви: на рівні речення (Малим мене мати в ромашиі купала (Поповський, 2020: 12), ...та й на порі стали (Поповський, 2020: 57); Гей, літа, не сnішіmь! (Поповський, 2020: 56)) та словосполучення (калинові уста (Поповський, 2020: 54), джерельна водиия (Поповський, 2020: 12), пишна калина (Поповський, 2020: 12), вклонитись низенько (Поповський, 2020: 65), на щзастя, на радість, на щедрую долю (Поповський, 2020: 92)). Особливо частотним у ліриці А. М. Поповського, як було зазначено, є багатофункційний вигук гей, типово вживаний у колоквіальному синтаксисі народних пісень 
в окличних реченнях. Поет уживає його у функції вираження емоцій (піднесення, захоплення та ін.), як-от: Зоряні дороги, гей, зійились до купи (Поповський, 2020: 36), а в окличних реченнях - у функції оклику в процесі звертання або заохочення до дії: Гей, зозуле, накуй у дубовім гаю (Поповський, 2020: 65) та ін.

Рисою авторського поетичного стилю $€$ частотне вживання прикладок: бджола-трудівниия, ковалик-дятел, бджола-медовиия, чарівниия-зима, красень-Березень, літа-ластів'ята, осінь-красуня, недруги-зайди та ін.

У текстах поезій знаходимо словосполучення, що мають у складі спільнокореневі деривати, як-от: намріється мрія (Поповський, 2020: 49), струмок струмить (Поповський, 2020: 62). Таке тавтологічне поєднання слів сприяє конденсації висловлення (Вихованець, 1988: 133) i, як наслідок, інтенсифікації омовлених у такий спосіб смислів та емоцій. Трапляється, що словосполучення містить спільнокореневі лексеми, одна з яких є оказіоналізмом, як-от: мільйонам тих іменних ŭ безіменних (Поповський, 2020: 63). У такому разі деривати, у яких повторюється спільна коренева морфема, - носії загальної семантичної ідеї, конкретизованої словотворчими формантами відповідно до комунікативних завдань тексту, забезпечують інтеграцію тексту, зв’язок його компонентів (Грещук, 2019: 48).

Поет часто використовує різного роду повтори на лексичному, синтаксичному, морфемному рівнях мови. Знаходимо анадіплозис: Осиротів мій добрий сад. Осиротів (Поповський, 2020: 23), Осиротів мій рідний дім, осиротів... (Поповський, 2020: 25), анафори: I немає рідних, і немає мам... (Поповський, 2020: 52), За всі страждання матерів і вдів,/ За всі убивства праві і неправі,/ За сльози сиріт, бранок і дідів... (Поповський, 2020: 63).

Мова поета образна, багата на метафори: Над морем стиглих $\breve{u}$ повних колосків (Поповський, 2020: 17), Зима бринить січневою струною (Поповський, 2020: 26), шовк зелених трав (Поповський, 2020: 36), I дощ, невпинно свою гречку сіє (Поповський, 2020: 63), На святкові столи ляжуть обруси маминих рук (Поповський, 2020: 55); метафоричні епітети: осамітнені думи (Поповський, 2020: 34), знедолена Вкрайна (Поповський, 2020: 20); дрімотна байдужість (Поповський, 2020: 11), терниста стежка (Поповський, 2020: 52), зоряні дороги (Поповський, 2020: 36); персоніфікації: I щиро споєна земля 
всміхнеться сонию золотому (Поповський, 2020: 18), чарівниия-зима покриває світ білизною пухкою (Поповський, 2020: 26), назустріч ранок з сонием виринав (Поповський, 2020: 36), роси окропили шовк зелених трав (Поповський, 2020: 36), Красень-Березень квіти дарує (Поповський, 2020: 54), В гості зима осінь холодно кличе (Поповський, 2020: 61); зевгми: I богоправедна наука перстом укаже, хто був раб, а хто - герой, а хто - падлюка (Поповський, 2020: 22), а також гіперболи: Твоя душа обняти рада б світ,/ Його зігріти й щзастя дарувати (Поповський, 2020: 53), безтямно тюбили (Поповський, 2020: 86) та ін. Трапляються метонімії: А по зоряному небу котить повне коло (Поповський, 2020: 27), Душа, як скрипка, плаче і сміється (Поповський, 2020: 53); клімакс: Коли в душі твоїй тривога, жагучий сум і щемний біль (Поповський, 2020: 22), Гори, гори! Палай, свята надіє (Поповський, 2020: 60), А не зальотника, хамлюгу і злочиния (Поповський, 2020: 41); порівняння: Душа, як скрипка (Поповський, 2020: 53); антитези: Поетів тьма! Поетів справжніх мало (Поповський, 2020: 29), риторичні запитання: Чи добре ие? Чи, може, вельми зле? (Поповський, 2020: 29), Куди ж летите?, Чи огорнете душу стражденну мою? (Поповський, 2020: 56) та ін.

Спільнокореневі деривати знаходимо, приміром, у таких рядках: Й поринала сама в самоту / Осамітнених дум (Поповський, 2020: 34), коли три спільнокореневі лексеми (означальний займенник, іменник і дієприкметник) ужиті в одному реченні один за одним, підсилюють думку поета про самотність ліричної героїні.

Плодами авторського словотвору є новотвори - nizмe-nampiomu (Поповський, 2020: 30), псевдопозичені поклони (Поповський, 2020: 31), Дніпробатьківщина (Поповський, 2020: 87) та ін. Авторські неологізми утворюють численні метафори: мово, розквітнеш трояндно (Поповський, 2020: 11), нищать зловрожо наш цввіт Украйни (Поповський, 2020: 11), обездружене лице (Поповський, 2020: 22) та ін. У поезіях А. М. Поповського трапляються новотвори, утворені шляхом складання основ, хоча витоки таких оказіоналізмів досить різні, зокрема:

- словосполучення, складники якого пов'язані відношеннями кореляції, де прикладка корелює з головним словом. Утворення нової лексеми відбувається усіченням однієї з основ і їхнім складанням (nігмеї-патріоти $\rightarrow$ nігме-патріоти); 
- словосполучення, складники якого пов'язані відношеннями узгодження і уналежнюються до групи підмета. Складник словосполучення, утвореного на основі узгоджених слів, перетворюється на прислівникову форму, що переходить до групи присудка ((хто?) Злі вороги нищать $\rightarrow$ нищать (як?) зловрожо). В утвореному внаслідок перенесення словосполучення з теми до реми неологізмі знову активізується попередня тема, яка стала в ньому ремою, унаслідок чого реалізується зв’язність і прогресія тексту, про що повідомлялося й раніше: «Словотвірні пари «твірне - похідне» слугують реалізації однієї з формально-структурних категорій тексту - прогресії» (Грещук, 2019: 50).

\section{Висновки}

Отже, поезіям А. М. Поповського властивий осібний стиль, якому притаманне частотне використання метафор, персоніфікації, різного роду повтори, новотвори, прикладки, спільнокореневі деривати, фольклорні мотиви, зокрема народнопоетична лексика й синтаксис, що, однак, потребує більш докладного дослідження. Зокрема, перспективним видається прагмалінгвістичний аналіз мовної особистості А. М. Поповського та подальше вивчення наповнення й структури виокремлених в його поезіях концептів.

Підсумовуючи, можемо впевнено сказати, що для поетичної мовної картини світу А. М. Поповського характерне органічне поєднання національного образного світу й власне авторського, філософськи осмисленого погляду на життя. Збірка філософських поезій А. М. Поповського - це самобутні художні твори, у яких перли життєвої мудрості автора омовлені виразним і неповторним авторським стилем.

\section{ЛІТЕРАТУРА}

1. Вихованець, I. Р. (1988) Частини мови в семантико-граматичному аспекті: моногр. Київ: Наук. думка. 2. Ірещук, В. (2019). Словотвір у текстотворенні. Вісн. Львів. ун-ту. Серія філологічна, 70, 43-51. 3. Загнітко, А. П. (2016). Категорійний і парадигмальний простір сучасної лінгвоперсонології. Studia Linguistica, 9, 150-159. 4. Калашник, В. С. (2011). Мовна особистість митця в індивідуально-авторській поетичній картині світу (спостереження над лірикою збірки Анатолія Мойсієнка «Спалені камені»). У Калашник, В. С. Людина та образ у світі мови: вибр. ст. (с. 248-252). Харків: ХНУ імені В. Н. Каразіна. 5. Кононенко, В. І. (2004). Концепти украйнського дискурсу. Київ-Івано-Франківськ: Плай. 6. Космеда, Т. А. (2012). EGO I ALTER EGO Тараса Шевченка в комунікативному просторі щоденникового дискурсу. Дрогобич: 
Коло. 7. Мацько, Л. І. (2014). Мовна особистість Тараса Шевченка як чинник формування національної ідентичності. Наук. зап. Нац. ун-ту «Острозька академія». Серія «Філологічна», 50, 8-15. 8. Невська, Ю. В. (2019). Дискурсиви в епістолярії М. Куліша: комунікативно-прагматичний вимір. Харків: ХІФТ. 9. Поповський, А. М. (2020). У роздумах плинного часу. Дніпро: Ліра. 10. Романченко, А. П. (2013). Семантичні типи порівнянь у художньому мовленні Ліни Костенко. Записки з украӥнського мовознавства, 20, 43-50. Узято з http://nbuv.gov.ua/UJRN/zukm_2013_20_8.

\section{REFERENCES}

1. Vykhovanets, I. R. (1988) Chastyny movy v semantyko-hramatychnomu aspekti [Parts of speech in the semantic-grammatical aspect]. Kyiv: Nauk. dumka [in Ukrainian]. 2. Greshchuk, V. (2019). Slovotvir u tekstotvorenni [Word building in text formation]. Visn. Lviv. un-tu. Seriia filolohichna - Bulletin of Lviv University. Philological series, 70, 43-51 [in Ukrainian]. 3. Zahnitko, A. P. (2016). Katehorinyi i paradyhmalnyi prostir suchasnoi linhvopersonolohii [Categorical and paradigmatic space of modern linguopersonology]. Studia Linguistica, 9, 150-159 [in Ukrainian]. 4. Kalashnyk, V. S. (2011). Movna osobystist myttsia v indyvidualno-avtorskii poetychnii kartyni svitu (sposterezhennia nad lirykoiu zbirky Anatoliia Moisiienka "Spaleni kameni") [Linguistic personality of the artist in the individual author's poetic picture of the world (observation of the lyrics of the collection of Anatoly Moisienko "Burnt Stones")]. In Kalashnyk, V. S. Liudyna ta obraz u sviti movy Man and image in the world of language (c. 248-252). Kharkiv: KhNU imeni V. N. Karazina [in Ukrainian]. 5. Kononenko, V. I. (2004). Kontsepty ukrainskoho dyskursu [Concepts of Ukrainian discourse]. Kyiv-Ivano-Frankivsk: Plai [in Ukrainian]. 6. Kosmeda, T. A. (2012). EGO I ALTER EGO Tarasa Shevchenka $v$ komunikatyvnomu prostori shchodennykovoho dyskursu [Taras Shevchenko's EGO I ALTER EGO in the communicative space of the diary discourse]. Drohobych: Kolo [in Ukrainian]. 7. Matsko, L. I. (2014). Movna osobystist Tarasa Shevchenka yak chynnyk formuvannia natsionalnoi identychnosti [Taras Shevchenko's linguistic personality as a factor in the formation of national identity]. Nauk. zap. Nats. untu "Ostrozka akademiia". Seriia "Filolohichna", 50, 8-15 [in Ukrainian]. 8. Nevska, Yu. V. (2019). Dyskursyvy v epistoliarii M. Kulisha: komunikatyvno-prahmatychnyi vymir [Discourse markers in the epistolary of M. Kulish: communicative-pragmatic dimension]. Kharkiv: KhIFT [in Ukrainian]. 9. Popovskyi, A. M. (2020). U rozdumakh plynnoho chasu [In the reflections of the flowing time]. Dnipro: Lira [in Ukrainian]. 10. Romanchenko, A. P. (2013). Semantychni typy porivnian u khudozhnomu movlenni Liny Kostenko [Semantic types of comparisons in Lina Kostenko's poetic speech]. Zapysky z ukrainskoho movoznavstva Notes on Ukrainian linguistics, 20, 43-50. Retrieved from http://nbuv.gov.ua/UJRN/ zukm_2013_20_8 [in Ukrainian].

Невсвка Юлія Володимирівна - кандидат філологічних наук, доцент кафедри англійської фонетики і граматики, Харківський національний педагогічний університет імені Г. С. Сковороди; вул. Валентинівська, 2, м. Харків, 61168, Україна.

Tel.: +380572681162

E-mail: yuliia.nevska@hnpu.edu.ua

https://orcid.org/0000-0001-6512-3595 
Nevska Yuliia Volodymyrivna - Candidate of Philological Sciences (Ph.D.), Associate Professor at the Department of English Phonetics and Grammar, H. S. Skovoroda Kharkiv National Pedagogical University; 2 Valentynivska Str., Kharkiv, 61168, Ukraine.

Надійшла до редакції 21 лютого 2021 року

\section{CITATION}

ДСТУ 8302:2015: Невська Ю. В. Поетична мовотворчість А. М. Поповського. Лінгвістичні дослідження: зб. наук. пр. Харк. нац. пед. ун-ту імені Г. С. Сковороди. Харків, 2021. Вип. 54. Ч. І. С. 155-164. DOI: https://doi.org/10.34142/23127546.2021. 54.1.13

АРА: Невська, Ю. В. (2021). Поетична мовотворчість А. М. Поповського. Лінгвістичні дослідження, 54 (I), 155-164. DOI: https://doi.org/10.34142/23127546.2021.54.1.13 